\title{
Inflammatory Biomarkers in Asian Indian Women with Metabolic Syndrome
}

\author{
Pooja R. Singhania ${ }^{1}$, Garima Gupta ${ }^{2}$, Kasturi Sen Ray ${ }^{1^{*}}$ \\ ${ }^{1}$ Department of Food Science and Nutrition, S.N.D.T. Women's University, Mumbai, India; ${ }^{2}$ S.V.T. College of Home Science, \\ S.N.D.T. Women's University, Mumbai, India. \\ Email: pisceanpooja@gmail.com,garima77777@gmail.com, *kasturisenray@gmail.com
}

Received May 22 ${ }^{\text {nd }}, 2013$; revised June 22 ${ }^{\text {nd }}, 2013$; accepted June $29^{\text {th }}, 2013$

Copyright (C) 2013 Pooja R. Singhania et al. This is an open access article distributed under the Creative Commons Attribution License, which permits unrestricted use, distribution, and reproduction in any medium, provided the original work is properly cited.

\begin{abstract}
Cardiovascular diseases (CVD) are the leading cause of mortality necessitating its early detection. The emergence of newer subclinical biomarkers in addition to the known cardiometabolic risk factors may play an important role in early detection of CVD risk. In the present study, 74 adult females (30 - 75 y) with metabolic syndrome (MS) were selected and additional biochemical parameters such as C-reactive protein (CRP) and Homocysteine (Hcy) levels were analyzed. The average body mass index (BMI) and waist circumference of subjects were found to be $30 \mathrm{~kg} / \mathrm{m}^{2}$ and $99 \mathrm{~cm}$ respectively. Mean LDL levels were found to be much higher than normal $(139 \mathrm{mg} / \mathrm{dl})$ while the HDL levels were low $(41.5$ $\mathrm{mg} / \mathrm{dl}$ ). The average fasting blood sugar and insulin levels were within the normal range. However, $40.5 \%$ females had serum Hcy levels $>13.2 \mu \mathrm{mol} / 1$ and $59.5 \%$ women had CRP levels $>3 \mathrm{mg} / \mathrm{L}$ indicating increased risk of CVD. Higher Hcy levels were associated with hyperinsulinemia $(\mathrm{p}<0.01)$ and hyperglycemia $(\mathrm{p}<0.05)$, indicating predilection for glucose intolerance. CRP levels showed significant negative correlation with HDL $(\mathrm{p}<0.05)$, indicating a predilection for glucose intolerance. The present study reports overall more than $40 \% \mathrm{MS}$ women are classified as high risk group using the Western standards. Limited data on normal levels of inflammatory biomarkers are available for Asian Indians. The study results indicate the importance of Hcy and CRP values among females having metabolic syndrome, known to be at a high risk of CVD.
\end{abstract}

Keywords: Metabolic Disorder; Inflammatory Biomarkers; Homocysteine; C-Reactive Protein; Asian Indians; Metabolic Syndrome

\section{Introduction}

Metabolic syndrome (MS) is defined as a cluster of the most dangerous heart attack risk factors: diabetes and prediabetes, abdominal obesity, high cholesterol and high blood pressure [1]. M. Thiruvagounder et al. (2010) [2] reported that people with MS are about twice as likely to develop cardiovascular disease (CVD) and over four times as likely to develop Type 2 diabetes compared to subjects without metabolic syndrome. Asian Indians have strong predisposition to MS and CVD [3], which has been shown through several studies on Indians living in India $[4,5]$ and abroad [6,7].

Traditional CVD risk factors account for only around $50 \%$ of cardiovascular morbidity and mortality [8]. Thus, the importance and utility of newer predictors have been emphasized as an additional means of early detection of CVD risk [9]. These novel markers may be useful in pre-

${ }^{*}$ Corresponding author. dicting risk in addition to the conventional risk factors [10].

The $20^{\text {th }}$ century has seen the emergence of substantial evidence to prove homocysteine (primarily atherogenic marker), C-reactive protein and fibrinogen (primarily thrombosis marker) $[1,11]$ as the newer risk factors for CVD amongst Asian Indians.

Homocysteine (Hcy), a homologue of the naturally occurring amino acid cysteine, has been touted as one of the new-age inflammatory markers of CVD risk. In 1969, autopsy of children with homocystinuria revealed presence of severe atherosclerosis demonstrating pathogenic role of homocysteine [12]. Thereafter, the second phase of NHANES III (1991-1994) included study of homocysteine understanding its significance as more than just a marker of vitamin deficiency. A study by R. Carmel et al. (2002) [13] found that Asian Indian population residing in US have significantly higher Hcy levels compared 
to men from 4 other ethnic groups with $25.6 \%$ being hyperhomocysteinemic. They concluded that hyperhomocysteinemia is common among apparently healthy Asian Indian men accompanied by subclinical cobalamin deficiency.

Similarly, P.E. Szmitko et al. (2003) [14] reported that CRP may play a direct active role in the pathogenesis of atherosclerosis through its inflammatory action in blood vessels. C-reactive protein (CRP) is an acute phase reactant that increases in response to systemic inflammation such as infection or tissue injury [15]. Inflammation causes release of cytokines, especially Interlukin-6, which is largely responsible for triggering the production of CRP from the liver. Studies have shown that high sensitivity CRP consistently predicts new coronary events in patients with unstable angina and acute myocardial infarction $[16,17]$.

The normal levels for the Homocysteine and CRP have been calculated for the Western population. The present study has assessed the Homocysteine and CRP level among Asian Indians with metabolic syndrome at risk for CVD and compared the value with the normal data.

\section{Material and Methods}

\subsection{Sample}

Female subjects in the age group of $30-75$ yr were screened for the presence of 3 or more of the following symptoms to be classified as having metabolic syndrome [18]:

- Waist circumference $>80 \mathrm{~cm}$ in women

- Blood pressure (BP) $\geq 130 / 85$ or medical treatment of previously diagnosed hypertension

- Triglycerides (TG) $\geq 150 \mathrm{mg} / \mathrm{dL}$

- Low levels of High Density Lipoprotein (HDL) Cholesterol in women $<50 \mathrm{mg} / \mathrm{dL}$

- Fasting blood sugar (glucose) $\geq 110 \mathrm{mg} / \mathrm{dL}$

A total of 74 female were then enrolled based on written informed consent.

The proposal was approved by the Institutional Ethics committee of Department of Pharmacology, Grant medical College and Sir J.J. Group of Hospitals, Byculla, Mumbai.

The basic information of the subjects such as age, gender, caste was recorded. BMI and waist circumference were measured as per standard protocol.

\subsection{Blood Sampling}

$5 \mathrm{ml}$ of peripheral venous blood was collected by vein puncture using a dry, disposable syringe between $8 \mathrm{AM}$ $9 \mathrm{AM}$ after an overnight fast (10.5 - 12 hours). Blood was collected in sterile tubes containing EDTA as anticoagulant for plasma separation. For serum separation, blood was collected without EDTA. Plasma and serum were separated by centrifugation at $3000 \mathrm{rpm}$ for $15 \mathrm{~min}$ and were stored at $4^{\circ} \mathrm{C}$ and used for various biochemical assays.

\subsection{Biochemical-Analytical Methods}

Glucose: Fasting blood glucose was estimated using the GOD-POD method [19].

Total cholesterol: Serum total cholesterol level was assayed by the kit method of CHOD-PAP with ATCS method [19-22].

Triglyceride: Serum triglyceride level was estimated by using the GPO-POD method with ESPAS [23-27].

HDL-cholesterol: HDL-cholesterol was estimated by the method of HDL precipitating reagent [28-33].

LDL-cholesterol: Serum LDL-cholesterol was estimated from the primary measurements by using the empirical equation of Friedewald et al. 1972 [34].

Serum LDL cholesterol $=$ Total cholesterol $-($ HDL cholesterol - Triglyceride/5).

C-Reactive Protein: CRP Turbilatex with high sensitivity and specificity was used [35-41].

Homocysteine (Hcy): Automated enzymatic assay for homocysteine [42].

\subsection{Statistical Analysis}

Numerical data were presented as mean values \pm S.D. Pearson's correlation co-efficient was used to test the magnitude of association between the inflammatory markers and different anthropometric and biochemical tests.

\section{Results \& Discussion}

Subjects with metabolic syndrome were identified based on the guideline provided by modified National Cholesterol Education Program-Adult Treatment Panel III [18] for Asians. These include presence of higher abdominal waist circumference, high blood pressure, hypertriglyceridemia, low HDL cholesterol and. high blood glucose. Individuals exhibiting at least three or more of these parameters simultaneously were selected.

It has been noted that coronary artery disease occurs 10 years earlier among South Asian Indians compared to other populations across the world and develop metabolic abnormalities at a lower body mass index and waist circumference thereby leading to $25 \%$ to $50 \%$ underestimation of MS prevalence [43].

Table 1 shows the basic demographic profile of the subjects enrolled from the cosmopolitan city Mumbai, India. The average age of the women subjects was 50 years with majority being in obese category as indicated by a higher average BMI. BMI cut-offs for defining "overweight" and obesity in Asian Indians are $23 \mathrm{~kg} / \mathrm{m}^{2}$ and $25 \mathrm{~kg} / \mathrm{m}^{2}$ respectively [5]. 


\subsection{Traditional Indicators for CVD Risk}

\subsubsection{Central Obesity and High Blood Pressure}

Central obesity, high blood pressure and dyslipidemia are most common indicator for CVD risk. Table 2 shows that female subjects had the typical signs of metabolic syndrome with higher waist circumference and higher mean systolic and diastolic blood pressure. A. Misra et al. (2006) [44] suggested revision of waist circumference cut-offs to above $80 \mathrm{cms}$ among Asian Indians since metabolic abnormalities contributing to cardiovascular risk factors are detectable at a lower waist circumference in Asians.

\subsubsection{Lipid Profile}

Figure 1 shows that although the average total cholesterol was only slightly elevated as compared to the normal range, the increased LDL cholesterol and low HDL cholesterol levels independently may increase the risk of cardiovascular disease. Dyslipidemia among women subjects further increases the risk of atherosclerosis [45]. E. Dhanaraj et al. (2009) [46] noted that HDL-C was stronger predictor of MS among women compared to men.

\subsubsection{Fasting Blood Sugar and Insulin Level}

M. Thiruvagounder et al. (2010) [2] reported that people with MS are over four times as likely to develop type 2 diabetes compared to subjects without metabolic syndrome. As shown in Table 3, the average fasting blood sugar levels of the women was within normal range with only $8 \%$ women having levels greater than $100 \mathrm{mg} / \mathrm{dL}$. The average fasting insulin levels were found to be within the normal range (Table 3). R. Mack et al. (2004) [48] reported significantly higher mean fasting insulin

Table 1. Demographic profile of the enrolled subjects $(n=$ 74).

\begin{tabular}{cccc}
\hline Parameter & Mean \pm SD & Min & Max \\
\hline Age $(\mathrm{yrs})$ & $50 \pm 10$ & 30 & 75 \\
Weight $(\mathrm{kg})$ & $71.2 \pm 12.4$ & 50 & 105 \\
BMI $\left(\mathrm{kg} / \mathrm{m}^{2}\right)$ & $29.9 \pm 5$ & 20.36 & 46.7 \\
\hline
\end{tabular}

Table 2. Values of common indicators in selected subjects (n =74).

\begin{tabular}{ccccc}
\hline Parameter & Mean \pm SD & Min & Max & Ref values $^{*}$ \\
\hline WC (cm) & $98.7 \pm 12$ & 67 & 132 & $80 \mathrm{~cm}$ \\
BP (mmHg) & $128 / 84$ & $110 / 60$ & $160 / 110$ & $130 / 85$ \\
Systolic BP (mmHg) & $128 \pm 11.6$ & 110 & 160 & 130 \\
Diastolic (mmHg) & $84 \pm 8.4$ & 60 & 110 & 85 \\
\hline
\end{tabular}

*Modified NCEP ATP III 2006 [18].

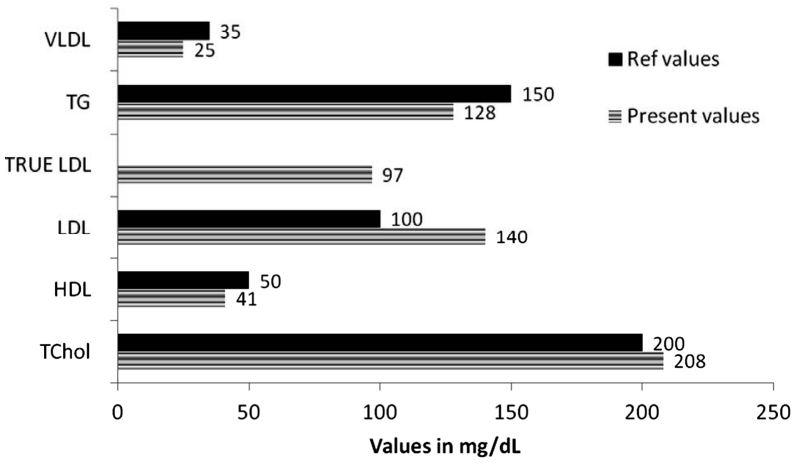

Figure 1. Lipid profile of metabolic syndrome subjects (AACE 2012 [45]).

Table 3. Blood sugar and insulin in women with metabolic syndrome $(n=74)$.

\begin{tabular}{ccccc}
\hline Parameter & Mean \pm SD & Min & Max & Ref value \\
\hline FBS $(\mathrm{mg} / \mathrm{dL})$ & $86.6 \pm 10.5$ & 68 & 129 & $\geq 100^{\$}$ \\
Fasting Insulin $(\mu \mathrm{IU} / \mathrm{mL})$ & $13.1 \pm 6.9$ & 4.21 & 47.7 & NA \\
HbA1c $(\%)$ & $6.01 \pm 0.6$ & 4.9 & 8.3 & $<6^{\&}$ \\
\hline
\end{tabular}

${ }^{\$}$ NHLBI 2010, ${ }^{\&}$ I.A. Syed \& W.A. Khan 2011 [47].

levels in individuals with diabetes $(29.1 \mu \mathrm{IU} / \mathrm{mL})$ compared to non-diabetic $(15.8 \mu \mathrm{IU} / \mathrm{mL})$ and only $9.2 \%$ non-diabetics having elevated insulin levels $>27 \mu \mathrm{IU} / \mathrm{mL}$ compared to $29.7 \%$ diabetics. As the range for normal fasting insulin is very wide $(2-25 \mu \mathrm{IU} / \mathrm{mL})$, it may be difficult in predicting disease risk, especially with insulin resistant or insulin deficient diabetic condition.

In the present study, $72.9 \%$ women had serum insulin levels $>10 \mu \mathrm{IU} / \mathrm{mL}$. In a similar study on 45 non diabetic patients, fasting insulin level higher than $10 \mathrm{microIU} / \mathrm{mL}$ was associated with 11 fold increased probability of coronary artery disease [49].

\subsubsection{Glycosylated Protein}

HbA1C levels also have a strong association with metabolic syndrome that persists after adjusting for age and sex [50]. In the present study, the average fasting $\mathrm{HbA} 1 \mathrm{c}$ levels were found to be within the normal range (Table 3).

\subsection{New Indicators for CVD Risk}

\subsubsection{Homocysteine}

Table 4 shows that the average Homocysteine (Hcy) levels of the female subjects were $14.4 \mu \mathrm{mol} / \mathrm{l}$; higher than the range of normal serum homocysteine levels of 2.2 to $13.2 \mu \mathrm{mol} / 1$ [51]. $40.5 \%$ females had serum homocysteine levels greater than $13.2 \mu \mathrm{mol} / 1$ may indicate higher risk of cardiovascular disease.

Several studies among the Western population have 
found that homocysteine levels up to $14-15 \mu \mathrm{mol} / 1$ was associated with significantly increased mortality rate [52-54]. Higher Hcy levels even at levels considered as normal are associated with increased health risks [55]. Experts suggest that target of $<7-8 \mu \mathrm{mol} / \mathrm{l}$ is the optimal range that should be maintained in individuals over 30 years of age to prevent complications [56]. L. Broxmeyer (2004) [57] observed increased risk of atherosclerosis, heart attack and stroke in adults with Hcy values $\geq 6.3$ $\mu \mathrm{mol} / \mathrm{l}$.

B.S. Raheja \& M. Talim (2000) [58] have proposed that in Asian Indians, factors such as traditional cooking practices with prolonged heating of vegetables leading to destruction of folate, increased use of processed and refined cereal products deficient in vitamin B6 such as bread, cakes and cookies, and use of fibrates to lower triglycerides [59] can contribute to increased homocysteine levels in addition to faulty fat intake.

\subsubsection{C-Reactive Protein}

Figure 2 indicates that highly elevated CRP level ( $\geq 3$ $\mathrm{mg} / \mathrm{L}$ ) was observed in $59.5 \%$ subjects. This supports the findings by A. Misra et al. [5] that adult Asian Indians have higher CRP levels than other populations with greater susceptibility to Type 2 diabetes mellitus and coronary heart disease. According to A. Misra et al. [5], elevated CRP in Asian Indians may be associated with excess body fat (subcutaneous fat) and physical inactivity but relationship with inflammation and protein deficiency need to be explored.

It was also observed that out of the 44 women with serum CRP levels $\geq 3 \mathrm{mg} / \mathrm{L}, 91 \%$ were in the obese category (BMI $\left.>25 \mathrm{~kg} / \mathrm{m}^{2}\right)$. Aronson et al. (2004) [60] have

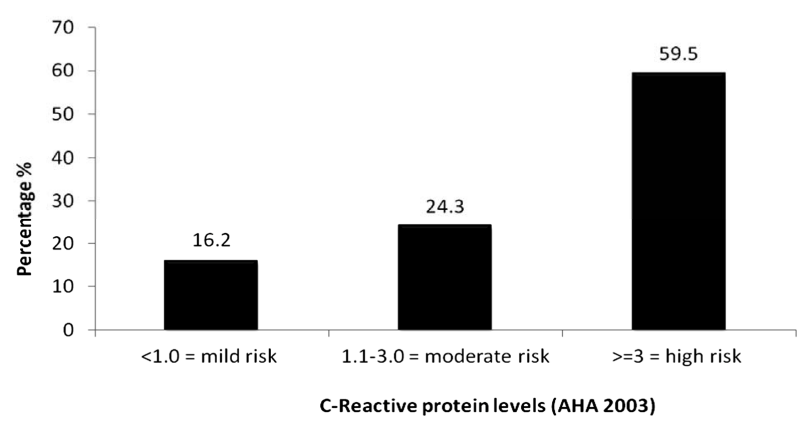

Figure 2. CRP risk stratification among the MS Subjects (n = 44).

Table 4. Inflammatory markers in metabolic syndrome subjects.

\begin{tabular}{ccccc}
\hline Parameter $(\mathbf{n}=\mathbf{7 4})$ & Mean \pm SD & Min & Max & Ref values \\
\hline Hcy & $14.4 \pm 6$ & 1.3 & 32.4 & $2-12 \mu \mathrm{mol} / \mathrm{L}$ \\
CRP & $5.6 \pm 4.5$ & 0.3 & 18.3 & $<1 \mathrm{mg} / \mathrm{L}$ \\
\hline
\end{tabular}

also reported significantly higher CRP levels in obese individuals compared to non-obese. Also, $79.5 \%$ of the women with elevated CRP levels were found to have waist circumference much higher than normal range ( $>89$ $\mathrm{cm})$.

The American Heart Association [61] suggested that hs-CRP may have a role in risk stratification of patients with established CVD, although more data are needed to compare the prognostic value of elevated levels of hsCRP with other measures currently in use. Prospective data among apparently healthy men suggest that CRP levels may be useful in identifying those at an increased long-term risk of sudden cardiac death [62].

\subsubsection{Correlation of Inflammatory Markers with Other Cardiometabolic Risk Factors}

The association between the inflammatory markers such as Hcy and CRP and the known cardiometabolic risk factors (MS) was noted. The study attempts to validate the importance of these additional novel biomarkers in relation to CVD prevention.

In the present study, there was significant positive correlation noted between Hcy and fasting insulin and high blood glucose (Table 5), indicating that high Hcy levels may be associated with hyperinsulinemia $(\mathrm{p}<0.01)$ and hyperglycemia $(\mathrm{p}<0.05)$.

A weak positive correlation of CRP levels with BMI and fasting insulin levels was also noted. In a similar study on Indian males, N.K. Vikram et al. (2006) [63]

Table 5. Correlation of inflammatory markers with other cardiometabolic risk factors.

\begin{tabular}{|c|c|c|c|c|}
\hline \multirow[t]{2}{*}{ Parameters } & \multicolumn{2}{|c|}{ CRP } & \multicolumn{2}{|c|}{ HCY } \\
\hline & $\mathbf{r}$ & $\mathbf{p}$ & $\mathbf{r}$ & $\mathbf{p}$ \\
\hline Weight & 0.187 & 0.116 & -0.052 & 0.669 \\
\hline BMI & 0.229 & 0.053 & -0.003 & 0.979 \\
\hline WC & 0.161 & 0.177 & 0.080 & 0.509 \\
\hline T-hol & $-0.293^{*}$ & 0.012 & -0.198 & 0.098 \\
\hline HDL-C & $-0.281^{*}$ & 0.016 & 0.124 & 0.302 \\
\hline LDL-C & -0.197 & 0.099 & -0.222 & 0.064 \\
\hline TG & 0.012 & 0.922 & 0.050 & 0.677 \\
\hline ESR & $0.346^{* *}$ & 0.003 & 0.183 & 0.131 \\
\hline FBS & 0.068 & 0.570 & $0.233^{*}$ & 0.050 \\
\hline Fasting Insulin & 0.226 & 0.055 & $0.373^{* *}$ & 0.001 \\
\hline $\mathrm{HbAlc}$ & 0.171 & 0.148 & -0.090 & 0.454 \\
\hline SysBP & 0.131 & 0.296 & -0.017 & 0.891 \\
\hline DiasBP & 0.140 & 0.262 & -0.065 & 0.602 \\
\hline
\end{tabular}

*Significant at $\mathrm{p}$ value $<0.05,{ }^{* *}$ Significant at $\mathrm{p}$ value $<0.01$. 
reported to have no correlation between markers of insulin resistance and hs-CRP levels.

It was observed that CRP levels negatively correlated with HDL-Cholesterol $(\mathrm{p}<0.05)$ indicating that as CRP levels increase, the HDL-Cholesterol may decrease. But in 2007, J.S. Wasir et al. [64] reported no interrelation between CRP and low HDL levels in postmenopausal women, stating both as independent risk factors for cardiovascular disease risk.

In a recent study on 45 - 60 years old male patients suffering from CAD at Coimbatore, India, P. Aparna et al. (2010) [65] reported higher serum homocysteine and CRP levels as compared to controls.

\section{Conclusion}

While Asian Indians have greater genetic predisposition and susceptibility to metabolic diseases, there is a strong need to detect it in early stages to take appropriate preventive measures. Although, the significance and prognostic value of inflammatory markers such as Hcy and CRP have been studied and well established for assessing CVD risk in the Western population, we lack sufficient evidence to replicate the findings among Asian Indians. The risk stratification among Asian Indians may begin at much lower values than Western standards requiring us to revise and re-establish population-specific normal values. The present study showed significant positive correlation between Hcy and fasting insulin and high blood glucose. The monitoring and evaluation of inflammatory markers alongside the metabolic risk factors will enable better understanding of metabolic disease prevention and progression.

\section{Acknowledgements}

The report is a part of larger project on Subclinical Parameters of Patients with Metabolic Syndrome, sponsored by Tata Global Beverage Ltd. We greatly acknowledge the support from Tata Global Beverage Ltd.

\section{REFERENCES}

[1] K. G. M. M. Alberti, P. Zimmet and J. Shaw, "Metabolic Syndrome-A New World-Wide Definition. A Consensus Statement from the International Diabetes Federation," Diabetic Medicine, Vol. 23, No. 5, 2006, pp. 469480. http://dx.doi.org/10.1111/j.1464-5491.2006.01858.x

[2] M. Thiruvagounder, S. Kha and D. S. Sheriff, "The Prevalence of Metabolic Syndrome in a Local Population in India," Biochemia Medica, Vol. 20, No. 2, 2010, pp. 249252. http://dx.doi.org/10.11613/BM.2010.031

[3] S. Kanjilal, J. Shanker, V. S. Rao, N. B. Khadrinarasimhaih, M. Mukherjee, S. S. Iyengar and V. V. Kakkar, "Prevalence and Component Analysis of Metabolic Syndrome: An Indian Atherosclerosis Research Study Perspective," Vascular Health Risk Management, Vol. 4, No.
1, 2008, pp. 189-197.

http://dx.doi.org/10.2147/vhrm.2008.04.01.189

[4] A. Ramachandran, I. Sathyamuthy, C. Snehaltha, K. Satyavani, S. Sivasankari, J. Misra, M. R. Girinath and V. Viswanathan, "Risk Variable for Coronary Artery Disease in Asian Indians," American Journal of Cardiology, Vol. 88, No. 2, 2001, pp. 201-202. http://dx.doi.org/10.1016/S0002-9149(01)01659-9

[5] A. Misra, J. W. Singh and R. M. Pandey, "An Evaluation of Candidate Definitions of the Metabolic Syndrome in Adult Asian Indians," Diabetes Care, Vol. 28, No. 2, 2005, pp. 398-403. http://dx.doi.org/10.2337/diacare.28.2.398

[6] C. Tan, S. K. Chew, M. Stefan, et al., "Can We Apply the NCEP-ATP Definition of the Metabolic Syndrome to Asians?" Diabetes Care, Vol. 27, No. 5, 2004, pp. 11821186. http://dx.doi.org/10.2337/diacare.27.5.1182

[7] T. Shah, S. S. Jonnalagadda, J. R. Kicklighter, et al., "Prevalence of Metabolic Syndrome Risk Factors among Young Adult Asian Indians," Journal of Immigrant Health, Vol. 7, No. 2, 2005, pp. 117-126. http://dx.doi.org/10.1007/s10903-005-2645-5

[8] M. Wei, B. D. Mitchell, S. M. Haffner and M. P. Stern, "Effects of Cigarette Smoking, Diabetes, High Cholesterol, and Hypertension on All Cause Mortality and Cardiovascular Disease Mortality in Mexican Americans. The San Antonio Heart Study," American Journal of Epidemiology, Vol. 144, No. 11, 1996, pp. 1058-1065. http://dx.doi.org/10.1093/oxfordjournals.aje.a008878

[9] D. S. Buchan, N. E. Thomas and J. S. Baker, "Novel Risk Factors of Cardiovascular Disease and Their Associations between Obesity, Physical Activity and Physical Fitness," Journal of Public Health Research, Vol. 1, No. 11, 2012, pp. 59-66.

[10] G. F. Gensini, M. Comeglio and A. Colella, "Classical Risk Factor and Emerging Elements in the Risk Profile for Coronary Artery Disease," European Heart Journal, Vol. 195, 1998, pp. 53A-61A.

[11] R. B. Harish, V. Govindaraju and C. N. Manjunath, "Risk Prediction-Homocysteine in Coronary Heart Disease," Indian Journal of Clinical Biochemistry, Vol. 22, No. 1, 2007, pp. 18-21. http://dx.doi.org/10.1007/BF02912875

[12] K. S. McCully, "Vascular Pathology of Homocysteinemia: Implications for the Pathogenesis of Arteriosclerosis," American Journal of Pathology, Vol. 56, No. 1, 1959, pp. 111-128.

[13] R. Carmel, P. V. Mallidi, S. Vinarskiy, S. Brar and Z. Frouhar, "Hyperhomocysteinemia and Cobalamin Deficiency in Young Asian Indians in the United States," American Journal of Hematology, Vol. 70, No. 2, 2002, pp. 107 114. http://dx.doi.org/10.1002/ajh.10093

[14] P. E. Szmitko, C. H. Wang, R. D. Weisel, J. R. de Almeida, T. J. Anderson and S. Verma, "New Markers of Inflammation and Endothelial Cell Activation: Part I," Circulation, Vol. 108, 2003, pp. 1917-1923. http://dx.doi.org/10.1161/01.CIR.0000089190.95415.9F

[15] M. Pepys, "C-Reactive Protein Fifty Years On," Lancet, Vol. 317, No. 8221, 1981, pp. 653-657. http://dx.doi.org/10.1016/S0140-6736(81)91565-8 
[16] L. M. Biasucci, "C-Reactive Protein and Secondary Prevention of Coronary Events," Clinica Chimica Acta, Vol. 311, 2001, pp. 49-52. http://dx.doi.org/10.1016/S0009-8981(01)00558-7

[17] F. Haverkate, S. G. Thompson, S. D. Pyke, et al., "Production of C-Reactive Protein and Risk of Coronary Events in Stable and Unstable Angina: European Concerted Action on Thrombosis and Disabilities Angina Pectoris Study Group," Lancet, Vol. 349, No. 9050, 1997, pp. 462-466. http://dx.doi.org/10.1016/S0140-6736(96)07591-5

[18] D. Heng, S. Ma, J. J. M. Lee, B. C. Tai, K. H. Mak, K. Hughes, et al., "Modification of the NCEP ATP III Definitions of the Metabolic Syndrome for Use in Asians Identifies Individuals at Risk of Ischemic Heart Disease," Atherosclerosis, Vol. 186, No. 2, 2006, pp. 367-373. http://dx.doi.org/10.1016/j.atherosclerosis.2005.07.020

[19] P. Trinder, "Determination of Glucose in Blood Using Glucose Oxidase with an Alternative Oxygen Acceptor," Annals of Clinical Biochemistry, Vol. 6, No. 2, 1969, pp. 24-27.

[20] G. Schettler and E. Nüssel, Arbeitsmed Sozialmed Präventivmed, Vol. 10, No. 25, 1975.

[21] W. Richmond, "Preparation and Properties of a Cholesterol Oxidase from Nocardia sp. and Its Application to the Enzymatic Assay of Total Cholesterol in Serum," Clinical Chemistry, Vol. 19, No. 12, 1973, pp. 1350-1356.

[22] P. Roeschlau, "Enzymatische Bestimmung das GesamtChoiesterins in Serum," Zeitschrift für Klinische Chemie und Klinische Biochemie, Vol. 12, 1974, pp. 403-407.

[23] P. D. Mayne, "Fat Metabolism," In: Clinical Chemistry in Diagnosis and Treatment, Vol. 11. 6th Edition, Oxford University Press Inc., New York, 1994, p. 224.

[24] N. J. Jacobe and P. J. Van Demark, "The Purification and Properties of the $\alpha$-Glycerophosphate-Oxidizing Enzyme of Streptococcus faecalis 10C1," Archives of Biochemistry and Biophysics, Vol. 88, No. 2, 1960, pp. 250-255. http://dx.doi.org/10.1016/0003-9861(60)90230-7

[25] P. Trinder, "Triglycerides Estimation by GPO-PAP Method," Annals of Clinical Biochemistry, Vol. 6, No. 24, 1969, pp. 24-27.

[26] M. Werner, D. G. Gabrielson and J. Eastman, "Ultramicro Determination of Serum Triglycerides by Bioluminescent Assay," Clinical Chemistry, Vol. 27, No. 2, 1981, pp. 268271.

[27] L. K. Koditschek and W. W. Umbreit, "Alpha-Glycerophosphate Oxidase in Streptococcus faecium F 24," Journal of Bacteriology, Vol. 98, No. 3, 1969, pp. 10631068.

[28] W. P. Castelli, J. T. Doyle, T. Gordon, C. G. Hames, M. C. Hjortland, S. B. Hulley, A. Kagan and W. J. Zukel, "HDL Cholesterol and Other Lipids in Coronary Heart Disease: Cooperative Lipoprotein Phenotyping Study," Circulation, Vol. 55, No. 5, 1977, pp. 767-772. http://dx.doi.org/10.1161/01.CIR.55.5.767

[29] M. Burstein, H. R. Scholnic and R. Morfin, "Rapid Method for the Isolation of Lipoproteins from Human Serum by Precipitation with Polyanion," The Journal of Lipid Re- search, Vol. 11, No. 6, 1970, pp. 583-595.

[30] D. S. Young, "Effects of Drugs on Clinical Laboratory Tests," 3rd Edition, AACC Press, Washington, DC, Vol. 3, 1990, pp. 104-106.

[31] N. W. Tietz, "Textbook of Clinical Chemistry," W.B. Saunders, Philadelphia, 1986, pp. 874-881.

[32] W. Hohenwallner, R. Sommer, E. Wimmer and G. V. Tschurtschenthaler, Clinical Chemistry, Vol. 26, 1980, pp. 177,178

[33] N. W. Tietz, P. R. Finley and E. L. Pruden, "Clinical Guide to Laboratory Tests," 2nd Edition, W.B. Saunders, Philadelphia, 1990, pp. 304-306.

[34] W. T. Friedewald, R. I. Levy and D. S. Fredrickson, "Estimation of the Concentration of Low-Density Lipoprotein Cholesterol in Plasma, without Use of the Preparative Ultracentrifuge," Clinical Chemistry, Vol. 18, No. 6, 1972, pp. 499-502.

[35] H. Lars-Olof, et al., Current Opinion in Infect Diseases, Vol. 10, 1997, pp. 196-201. http://dx.doi.org/10.1097/00001432-199706000-00007

[36] C. Vaishnavi, Immunology and Infectious Diseases, Vol. 6, 1996, pp. 139-144.

[37] Y. Hokama, et al., Journal of Clinical Laboratory Status, Vol. 1, 1987, pp. 15-27.

[38] K. Pulki, et al., Scandinavian Journal of Clinical \& Laboratory Investigation, Vol. 46, 1986, pp. 606-607.

[39] W. Müller, et al., "Interference of IgM Rheumatoid Factor with Nephelometric C-Reactive Protein Determinations," Journal of Immunological Methods, Vol. 80, No. 1, 1985, pp. 77-90. http://dx.doi.org/10.1016/0022-1759(85)90166-8

[40] S. Otsuji, et al., Clinical Chemistry, Vol. 28, No. 10, 1982, pp. 2121-2124.

[41] D. S. Young, "Effects of Drugs on Clinical Laboratory Test," 4th Edition, AACC Press, Washington D.C., 1995.

[42] Y. Tan, X. Sun, L. Tang, N. Zhang, Q. Han, M. Xu, X. Tan, et al., "Automated Enzymatic Assay for Homocysteine," Clinical Chemistry, Vol. 49, No. 6, 2003, pp. 10291030. http://dx.doi.org/10.1373/49.6.1029

[43] E. A. Enas, V. Mohan, M. Deepa, S. Farooq, S. Pazhoor and H. Chennikkara, "The Metabolic Syndrome and Dyslipidemia among Asian Indians: A Population with High Rates of Diabetes and Premature Coronary Artery Disease," Journal of the Cardiometabolic Syndrome, Vol. 2, No. 4, 2007, pp. 267-275. http://dx.doi.org/10.1111/j.1559-4564.2007.07392.x

[44] A. Misra, N. K. Vikram, R. Gupta, R. M. Pandey, J. S. Wasir and V. P. Gupta, "Waist Circumference Cutoff Points and Action Levels for Asian Indians for Identification of Abdominal Obesity," International Journal of Obesity, Vol. 30, No. 1, 2006, pp. 106-111. http://dx.doi.org/10.1038/sj.ijo.0803111

[45] P. S. Jellinger, D. A. Smith, A. E. Mehta, O. Ganda, Y. Handelsman, H. W. Rodbard, M. D. Shepherd and J. A. Seibel, "The AACE Task Force for Management of Dyslipidemia and Prevention of Atherosclerosis," Endocrine Practice, Vol. 18, No. 1, 2012, pp. 8-11. 
[46] E. Dhanaraj, A. Bhansali, S. Jaggi, P. Dutta, S. Jain, P. Tiwari and P. Ramarao, "Predictors of Metabolic Syndrome in Asian North Indians with Newly Detected Type 2 Diabetes," The Indian Journal of Medical Research, Vol. 129, No. 5, 2009, pp. 506-514.

[47] I. A. Syed and W. A. Khan, "Glycated Haemoglobin-A Marker and Predictor of Cardiovascular Disease," Journal of Pakistan Medical Association, Vol. 61, No. 7, 2011, pp. 690-695.

[48] R. Mack, B. Skurnick, Y. Sterling-Jean, M. Pedra-Nobre and D. Bigg, "Fasting Insulin Levels as a Measure of Insulin Resistance in American Blacks," The Journal of Applied Research, Vol. 4, No. 1, 2004, pp. 90-94.

[49] E. Ekicibaşi, A. A. Kaderli, A. R. Kazazoğlu and B. Ozdemir, "Association of Microalbuminuria and Fasting Insulin Levels with Presence and Severity of Coronary Artery Disease in Non-Diabetic Cases," Anadolu Kardiyoloji Dergisi, Vol. 8, No. 1, 2008, pp. 16-21.

[50] J. Dilley, A. Ganesan, R. Deepa, M. Deepa, G. Sharada, O. D. Williams, et al., "Association of A1C with Cardiovascular Disease and Metabolic Syndrome in Asian Indians with Normal Glucose Tolerance," Diabetes Care, Vol. 30, No. 6, 2007, pp. 1527-1532. http://dx.doi.org/10.2337/dc06-2414

[51] F. M. Loehrer, R. Schwab, C. P. Angst, W. E. Haefeli and B. Fowler, "Influence of Oral S-Adenosylmethionine on Plasma 5-Methyltetrahydrofolate, S-Adenosylhomocysteine, Homocysteine and Methionine in Healthy Humans," The Journal of Pharmacology Experimental Therapeutics, Vol. 282, No. 2, 1997, pp. 845-850.

[52] A. G. Bostom, H. Silbershatz, I. H. Rosenberg, J. Selhub, R. B. D'Agostino, P. A. Wolf, P. F. Jacques and P. W. Wilson, "Non-Fasting Plasma Total Homocysteine Levels and All-Cause and Cardiovascular Disease Mortality in Elderly Framingham Men and Women," Formerly Archives of Internal Medicine, Vol. 159, No. 10, 1999, 1077-1080. http://dx.doi.org/10.1001/archinte.159.10.1077

[53] J. D. Kark, J. Selhub, B. Adler, J. Gofin, J. H. Abramson, G. Friedman and I. H. Rosenberg, "Nonfasting Plasma Total Homocysteine Level and Mortality in Middle-Aged and Elderly Men and Women in Jerusalem," Annals of Internal Medicine, Vol. 131, No. 5, 1999, pp. 321-330. http://dx.doi.org/10.7326/0003-4819-131-5-199909070-0 $\underline{0002}$

[54] S. E. Vollset, H. Refsum, A. Tverdal, O. Nygard, J. E. Nordrehaug, G. S. Tell and P. M. Ueland, "Plasma Total Homocysteine and Cardiovascular and Non Cardiovascular Mortality: The Hordaland Homocysteine Study," The American Journal of Clinical Nutrition, Vol. 74, No. 1, 2001, pp. 130-136.

[55] K. Robinson, E. L. Mayer, et al., "Hyperhomocysteinemia and Low Pyridoxal Phosphate: Common and Independent Reversible Risk Factors for Coronary Artery
Disease," Circulation, Vol. 92, No. 10, 1995, pp. 28252830. http://dx.doi.org/10.1161/01.CIR.92.10.2825

[56] R. R. McLean, P. F. Jacques, et al., "Homocysteine as a Predictive Factor for Hip Fracture in Older Persons," The New England Journal of Medicine, Vol. 350, No. 20, 2004, pp. 2042-2049.

http://dx.doi.org/10.1056/NEJMoa032739

[57] L. Broxmeyer, "Heart Disease: The Greatest 'Risk' Factor of Them All," Medical Hypotheses, Vol. 62, No. 5, 2004, pp. 773-779. http://dx.doi.org/10.1016/j.mehy.2003.12.018

[58] B. S. Raheja and M. Talim, "Homocysteine and Heart Disease in Indian Asians," The Lancet, Vol. 355, No. 9222, 2000, pp. 2249-2250. http://dx.doi.org/10.1016/S0140-6736(05)72745-8

[59] J. Dierkes, S. Westphal and C. Luley, "Serum Homocysteine Increases after Therapy with Fenofibrate or Bezafibrate," The Lancet, Vol. 354, No. 9174, 1999, pp. 219-220. http://dx.doi.org/10.1016/S0140-6736(99)02153-4

[60] D. Aronson, P. Bartha, O. Zinder, A. Kerner, W. Markiewicz, O. Avizohar, G. J. Brook and Y. Levy, "Obesity Is the Major Determinant of Elevated C-Reactive Protein in Subjects with the Metabolic Syndrome," International Journal of Obesity, Vol. 28, No. 5, 2004, pp. 674-679. http://dx.doi.org/10.1038/sj.ijo.0802609

[61] T. Pearson, G. A. Mensah, R. W. Alexander, J. L. Anderson, R. O. Cannon, M. Criqui, Y. Y. Fadl, S. P. Fortmann, et al., "Markers of Inflammation and Cardiovascular Disease: Application to Clinical and Public Health Practice: A Statement for Healthcare Professionals from the Centers for Disease Control and Prevention and the American Heart Association," Circulation, Vol. 107, No. 3, 2003, pp. 499-511. http://dx.doi.org/10.1161/01.CIR.0000052939.59093.45

[62] K. G. Alberti, P. Zimmet and J. Shaw, "IDF Epidemiology Task Force Consensus Group. The Metabolic Syndrome a New Worldwide Definition," The Lancet, Vol. 366, No. 9481, 2005, pp. 1059-1062. http://dx.doi.org/10.1016/S0140-6736(05)67402-8

[63] N. K. Vikram, A. Misra, R. M. Pandey, M. Dwivedi, K. Luthra, V. Dhingra and K. K. Talwar, "Association between Subclinical Inflammation \& Fasting Insulin in Urban Young Adult North Indian Males," Indian Journal of Medical Research, Vol. 124, No. 6, 2006, pp. 677-682.

[64] J. S. Wasir, A. Misra, N. K. Vikram, R. M. Pandey and K. Luthra, "C-Reactive Protein, Obesity, and Insulin Resistance in Post-Menopausal Women in Urban Slums of North India," Diabetes and Metabolic Syndrome: Clinical Research and Reviews, Vol. 1, No. 2, 2007, pp. 83-89.

[65] P. Aparna, A. Betigeri and P. Pasupathy, "Homocysteine and Oxidative Stress Markers and Inflammation in Patients with Coronary Artery Disease," International Journal of Biological and medical Research, Vol. 1, No. 4, 2010, pp. $125-129$. 